\title{
MUSIC STUDENTS` PREFERENCES FOR WORLD MUSIC IN THE CONTEXT OF STIMULATING INTERCULTURAL EDUCATION
}

\author{
UDC 78.036:(37.036:78)
}

\author{
Sonja S. Cvetković, Miomira M. Đurđanović ${ }^{\text {, }}$ \\ Marija M. Đorđević \\ ${ }^{1}$ University of Niš, Faculty of Arts, Niš, Serbia \\ ${ }^{2}$ MA Musical Theory and Pedagogy, Niš, Serbia
}

\begin{abstract}
The paper analyzes the phenomenon of world music and the preferences of music students from the Faculty of Arts of the University of Niš for this musical genre in the context of stimulating intercultural education. The research based on the descriptive method was conducted with the intention to obtain answers to questions about whether music students have knowledge/understanding of/for interculturality, to examine their attitudes towards different cultures, and whether they are ready to act against racial/cultural differences and prejudices. The results of this research were completed with the results of a survey, in which students evaluated selected examples of world music. This musical genre was chosen because in our opinion music is perceived not only as an autonomous artistic practice, but also as a representation of a particular culture, collective, and/or ethnic group. On the basis of the results, we tried to determine the students' reactions to the musical characteristics of the closer and distant cultural areas as well as their willingness to accept musical, linguistic and cultural differences in the context of the still dominant presence of the West European musical art in the process of academic education.
\end{abstract}

Key words: music students, music education, insterculturality, preferences, world music

\section{INTRODUCTION}

One of the main demands of global educational tendencies is the development of awareness of cultural diversity and the establishment of a balance in acquiring knowledge about different cultures. The concept of intercultural education that enables the

Received November 2018 / Accepted December 2018

Corresponding author: Sonja Cvetković

University of Niš, Faculty of Arts

E-mail: cvetkos@mts.rs 
acquisition of adequate competences is especially important in the academic education system, given the increasing possibilities of students mobility as well as the almost unlimited possibility of establishing communication in a modern information society. Intercultural education should prepare students for the acceptance of cultural, ethnic, linguistic and religious heterogeneity, as well as the challenges of today`s phenomena of globalization and migration that are accompanied by an increase in xenophobia, racial, ethnic and religious intolerance.

The aim of intercultural education is based on the assumption that plurality and cultural diversity are not only possible but also the main assumption of contemporary educational tendencies (Mansikka, Westvall \& Heimonen, 2018) while the intercultural competence is defined as the ability to successfully communicate and act in cross-cultural situations in different cultural contexts (Bennett \& Bennett, 2001).

Given the more or less accepted attitudes about universal aesthetics and ethical characteristics of art, intercultural education is also very important in the process of education of art students. In the academic teaching of music, the intercultural approach should be implied because during the entire educational process students become familiar with the music of different cultures and traditions from different stylistic/historical epochs by means of theoretical and practical teaching. The analysis of the curricula shows, however, that the main part of the educational content is still conventionally centered on the musical canon of Western Europe which can contribute to developing the awareness of the superiority of Western European music.

Precisely because of the need to overcome such stereotypes, one more often heard request is to learn not only about European music but also about the music of other cultures. This would enrich and expand the knowledge of students and enable them to better comprehend and understand the members of the further or closer communities, as well as of the community they belong to. Starting from the premise that music is at the same time the product of a culture and an active factor that constructs some culture, and through it certain ethnic identities, the implementation of such musical contents will enable the realization of three important segments of contemporary education: (1) inclusion of multicultural content; (2) paying attention to prejudices and stereotypes; (3) equality among students of different backgrounds in educational processes (Banks 1988).

According to Šulentić Begić (2010) the mutual diversity, but also the connection of particular cultures, today can be considered a special value. This is the reason why multicultural societies constantly encourage interculturality that points to the relations between these cultures and the need for mutual understanding-based interaction. "If we consider culture as a set of rituals that transform natural experiences into cultural modalities, knowing the codes of both our own and the codes of other cultures, we are not only gaining insight into the richness of the diversity of the cultural map of the world, but also in our own creativity and our own creative identity" (Cvetković \& Đurđanović 2013, 160). In order to achieve successful communication with the members of other cultures, it is important that besides getting to know their music, one also learns the language they speak, which can also be accomplished by listening to music examples where the lyrics are in different languages. Ethno music as well as world music "are a manifestations of the dialogue of national and ethnic cultures, since they can be inspired by the folklore culture of any national and ethnic community" (Arnautović 2017, 67). In this respect, the research of Henninger (2018) points to the necessity of including world music in the teaching process. Abril (2006) thinks it is ideal to give pupils/students the opportunity to 
listen to world music in the original language, which they later can sing for themselves. Providing students with the opportunity to listen and perform music that is representative for other cultures will positively affect their musical preferences (Fung 1994) and contribute to the increased sensitivity to world music (Dekaney et al. 2011). These contents will contribute "to the development of positive beliefs, convictions and attitudes about other peoples with whom they live and the values of their cultures" (Belojica Pavlović \& Cicović Sarajlić 2018, 36). Ober emphasizes that, in the beginning, the introduction of "music of others" into educational practice was experimental and marginal, but today it has assumed much wider range and lists a number of American and European universities that have opened departments for world music, and some of them are exclusively dealing with this kind of music $(2007,135)$.

Although the interest for world music dates back to the 1980s, attitudes have not yet been fully harmonized ${ }^{1}$ in defining this musical genre. Neither have the aesthetic criteria for its evaluation, which are probably the main reasons for the very sporadic implementation of world music into educational systems. Ober described world music as a popular music in which various experiences of many cultures are intertwined (2007, 105), emphasizing its cultural and musical hybridity. However, the same author points out that this is only a narrow meaning of this term, and that, in its wider sense, it can also denote the traditional music of non-Western civilizations (Ibid). Other authors specify the non-European origin of the main features of world music: "World music has an exotic origin, because its originating from the Third World, and accordingly to it is often attributed to inferiority, although at the same time one favors the good sides of its musical traditions" (Dobrota 2009, 157). Contrary to this opinion, some authors consider that the definition of world music as a music of non-Western civilizations can be problematic precisely because of the hybridity, that is, the mixing of various Western and nonWestern musical cultures (Ristivojević 2009, 122). Explaining the phenomenon of world music one also insists on commercial and marketing moments, closely related to the global popularity of this genre: "The term displays a peculiar, self-congratulatory pathos: a mesmerizing formula for a new business venture, a kind of shorthand figure for a new albeit fragmented - global economic reality with alluring commercial prospects“ (Erlmann 1996, 474).

\section{AIM, TASKS AND HYPOTHESES OF THE RESEARCH}

The primary aim of the research was to determine the attitudes of the students of the Department of Music at the Faculty of Arts in Niš towards world music in the context of the incentives of an intercultural education, and also the level of their satisfaction with listening to world music. Based on this formulated aim, certain tasks have been identified:

1. to examine whether there is knowledge/awareness of interculturality;

2. to examine the students`attitude of respect and appreciation of different cultures;

3. to examine whether there is students activity in the struggle against racial/cultural differences;

4. to examine students` preferences of world music.

\footnotetext{
${ }^{1}$ Beside the term "world music", in terms of synonyms for this genre there are also other terms like "folk music", "ethno music", "traditional music" etc.
} 
By means of the above mentioned research, the following hypotheses have been singled out:

H1: There is a knowledge/awareness of the students of the Faculty of Arts about interculturality.

H2: Students show respect and appreciation for different cultures.

H3: There is an impact of years of education on students activity in the struggle against $\mathrm{racial} / \mathrm{cultural}$ differences.

H4: There is no impact of years of study on students` preferences for world music.

\section{METHOD}

\subsection{Research sample}

The research was conducted on a sample $(\mathrm{N}=101)$ of selected students of the Faculty of Arts, Department for Music at the University of Niš. The research involved undergraduate students of the Music Theory and Pedagogy and the Performing Arts programs, and also graduate students of the Music Theory and Pedagogy program. Among them there were second year students (30 or $29.7 \%$ ), third year students ( 24 or $23.8 \%$ ), first year students ( 22 or $21.8 \%$ ), and finally fourth year students (15 or $14.9 \%$ ). The fewest students surveyed attended the master's program in Music Theory and Pedagogy (10 or $9.9 \%)$.

The representativeness of the sample was achieved by the choice of several age groups of subjects. The difference of one year between each group provided an insight into a wider range of age structure, but without a larger generation gap.

\subsection{Instrument and method of testing}

The research was based on the descriptive method. Surveying was used as a method to gather data. For this purpose, a previously designed questionnaire consisting of three parts was used (Dobrota 2016, 219-220). In the first part there are questions related to participants' sociodemographic data (type of studies, year of studies, and program). The Munroe Multicultural Attitude Scale Questionnaire (Dobrota, according to: Munroe, Pesarson 2006) was used in the second part, while in the third there were selected music excerpts from world music (duration of each example is one minute) that the students listened to. The participants expressed their attitude toward this examples by selecting one out of five claims offered in the questionnaire, and based on the Likert-type rating scale (I do not agree at all/ I don't like it at all - 1, I do not agree/ I don't like it2, I neither agree nor disagree/ I am neutral - 3, I agree/ I like it - 4, I fully agree/ I like it very mисh -5). In this way, the participants were able to express their views and assess the degree of liking of each musical example.

\subsection{Data processing and statistical methods applied}

The data obtained were processed in the SPSS Statistics 23.0 software package. Descriptive statistics used included frequencies (f), percentages (\%), means (M), and standard deviation (SD). To reach statistically valid conclusions, the analysis used the non-parametric Chi-square test, One-way ANOVA, and Paired Samples T-test. 


\section{RESULTS AND INTERPRETATIONS}

For the first hypothesis (H1): there is a knowledge/awareness of students about interculturality, certain research questions have been singled out: I am aware that racism exists, I am aware that different languages are spoken, I do not understand why members of different cultures behave in a different ways.

By means of the first question we wanted to examine how students of the Faculty of Arts perceived the claim that racism exists. The results of our research obtained on the basis of means $(M=4,42, S D=0,73)$ show that students are aware of and have a high degree of knowledge of the fact that racism exists. More than four fifths of all the participants $(89,2 \%)$ express agreement with the claim that racism exists. Of them, 55 students or $54,5 \%$ fully agree with this claim, while 35 or $34,7 \%$ express agreement. Two students $(2,0 \%)$ disagree with this claim and 9 students $(8,9 \%)$ express hesitancy (Table 1).

Table 1 Students`attitude on presence of racism, by year of studies

\begin{tabular}{|c|c|c|c|c|c|c|c|c|c|c|c|}
\hline \multirow[b]{2}{*}{ First } & \multicolumn{2}{|c|}{ I do not agree } & \multicolumn{2}{|c|}{$\begin{array}{c}\text { I neither agree } \\
\text { nor disagree }\end{array}$} & \multicolumn{2}{|c|}{ I agree } & \multicolumn{2}{|c|}{ I fully agree } & \multicolumn{2}{|r|}{ Total } & \multirow{7}{*}{$\begin{array}{c}\chi^{2}=24,791 \\
d f=12 \\
p=0,016\end{array}$} \\
\hline & 2 & $9,1 \%$ & 1 & $4,5 \%$ & 7 & $31,8 \%$ & 12 & $54,5 \%$ & 22 & $100,0 \%$ & \\
\hline Second & 0 & $0,0 \%$ & 2 & $6,7 \%$ & 13 & $43,3 \%$ & 15 & $50,0 \%$ & 30 & $100,0 \%$ & \\
\hline Third & 0 & $0,0 \%$ & 0 & $0,0 \%$ & 9 & $37,5 \%$ & 15 & $62,5 \%$ & 24 & $100,0 \%$ & \\
\hline Fourth & 0 & $0,0 \%$ & 2 & $13,3 \%$ & 3 & $20,0 \%$ & 10 & $66,7 \%$ & 15 & $100,0 \%$ & \\
\hline Master & 0 & $0,0 \%$ & 4 & $40,0 \%$ & 3 & $30,0 \%$ & 3 & $30,0 \%$ & 10 & $100,0 \%$ & \\
\hline Total & 2 & $2,0 \%$ & 9 & $8,9 \%$ & 35 & $34,7 \%$ & 55 & $54,5 \%$ & 101 & $100,0 \%$ & \\
\hline
\end{tabular}

Results of the Chi-square test: $\chi^{2}=24,791, \mathrm{df}=12, \mathrm{p}=0,016$ show a statistically significant difference in the attitude on the awareness of the fact that racism exists based on the year of studies. The highest percentage of the students of the undergraduate academic studies (more than 50\%) fully agree with the claim I am aware that racism exist while a significantly smaller percentage of the students of the master academic studies $(30 \%)$ agreed with this statement. Among the students of the master academic studies the largest number neither agree nor disagree with this attitude. Although the number is very small, it should be noted that only the students of the 1 st year of the undergraduate academic studies declared that they disagree with this claim, that is, they are not aware of the existence of racism. In the $2^{\text {nd }}$ and $4^{\text {th }}$ year, students are aware of this fact, while students of the 3rd year have shown the highest level of awareness about this phenomenon. All in all, the students of the undergraduate academic studies expressed more awareness (I agree and I fully agree) of the existence of racism than the students of the master academic studies.

The answers also indicate that students agree with the claim that different languages are spoken in the world, i.e. that they are aware of the existence of a languages different from their mother tongue and that the understanding of diversity requires the interconnection of different cultures. The largest number of students, 89 or $88.1 \%$, fully agreed with the claim that they accept the fact that there are different languages spoken in the world, $10(9,9 \%)$ disagreed, while only 2 participants $(2,0 \%)$ were indecisive.

For the statement I do not understand why members of different cultures behave in different ways, students`answers are evenly distributed $(\mathrm{M}=2,61, \mathrm{SD}=1,31)$. With this 
claim almost one quarter of participants, i.e. $25,7 \%$ of the students fully disagree. Almost the same number of students -24 or $23,8 \%$ do not agree with this claim. Half of the participants $(49.5 \%)$ understand the concept of diversity, and have knowledge of the diversity of cultures, as well as of the different behavior of their members. A total of 26 students or $25.7 \%$ are undecided (a quarter of participants), while with this statement agrees $13(12.9 \%)$ and fully agree $12(11.9 \%)$ students.

We can conclude that, unlike the statement that racism and different languages exist, for which students have a complete understanding, the behavior of members of different cultures has divided participants. Half of the students realize that members of different cultures behave in a different way from them, one-fourth is indecisive, and the secondfourth does not understand the different behavior of members of another culture.

Table 2 Students` attitude on the behavior of members of different cultures, by year of studies

\begin{tabular}{|c|c|c|c|c|c|c|c|c|c|c|}
\hline & $\begin{array}{c}\text { I do not } \\
\text { agree at all }\end{array}$ & $\begin{array}{l}\text { I do not } \\
\text { agree }\end{array}$ & $\begin{array}{r}\text { I nei } \\
\text { nor }\end{array}$ & $\begin{array}{l}\text { er agree } \\
\text { sagree }\end{array}$ & & agree & & $\begin{array}{l}\text { fully } \\
\text { gree }\end{array}$ & Total & \multirow{7}{*}{$\begin{array}{c}\chi^{2}=26,963 \\
d f=16 \\
p=0,042\end{array}$} \\
\hline First & $940,9 \%$ & $627,3 \%$ & 3 & $13,6 \%$ & 1 & $4,5 \%$ & 3 & $13,6 \%$ & $22100,0 \%$ & \\
\hline Second & $16,7 \%$ & $1033,3 \%$ & 12 & $40,0 \%$ & 1 & $3,3 \%$ & 2 & $6,7 \%$ & $100,0 \%$ & \\
\hline Third & $625,0 \%$ & $28,3 \%$ & 6 & $25,0 \%$ & 8 & $33,3 \%$ & 2 & $8,3 \%$ & $100,0 \%$ & \\
\hline Fourth & $426,7 \%$ & $320,0 \%$ & 2 & $13,3 \%$ & 3 & $20,0 \%$ & 3 & $20,0 \%$ & $100,0 \%$ & \\
\hline Master & $220,0 \%$ & $330,0 \%$ & 3 & $30,0 \%$ & 0 & $0,0 \%$ & 2 & $20,0 \%$ & $100,0 \%$ & \\
\hline Total & $2625,7 \%$ & $2423,8 \%$ & 26 & $25,7 \%$ & 13 & $12,9 \%$ & 12 & $11,9 \%$ & $101100,0 \%$ & \\
\hline
\end{tabular}

The statement I do not understand why members of different cultures behave in different ways cross tabulated with the participants' year of study and results of the Chisquare test: $\chi^{2}=26,963, \mathrm{df}=16, \mathrm{p}=0,042$ indicate that there is a certain difference in attitudes about the behavior of members of different cultures in relation to the level of education. It is interesting that the students of the initial years of the undergraduate studies $\left(1^{\text {st }}\right.$ and $2^{\text {nd }}$ ) show more understanding for cultural diversity, while in subsequent years answers are evenly distributed on the Likert scale, which indicates that students become indifferent or with less understanding for accepting diversity.

The second group of questions from the questionnaire referred to the student's sensitivity/concern/feeling for cultural differences. Similar to the first group of questions, in the second group students were required to express their views choosing one of the five statements (I do not agree at all - 1, I do not agree - 2, Neither agree nor disagree - 3, I agree - 4, I fully agree - 5).

The results of statistical data processing related to the attitude I am sensitive to different expressions of nationality show that the students are indifferent to the expressions of different nationality and the answers have an equal distribution $(\mathrm{M}=2,86, \mathrm{SD}=1,12)$. Namely, 42 participants or $41.6 \%$ circling number 3 on the Likert scale (I neither agree nor disagree). A total of 32 (31.6\%) students disagree with this statement, while $27(26.7 \%)$ agree - of which only 7 (6.9\%) fully agree, i.e. circling number 5 on the Likert scale.

Differences in students` attitude according to the level of education are minimal which also shows the results of the Chi-square test: $\chi^{2}=12,958, \mathrm{df}=16, \mathrm{p}=0,676$ which are not statistically significant.

Regarding the claim of racial inequality (I am emotionally concerned about racial inequality) student responses are evenly distributed on the Likert scale $(\mathrm{M}=2.93, \mathrm{SD}=$ 1.11). The largest number of students (36 or 35.6\%) circled number 3 , i.e. expressed 
indifference to this attitude. The racial inequality does not concern a total of 33 students $(32.7 \%)$, while $25(24.8 \%)$ agree with the concern about racial inequality, and only 7 students $(6.9 \%)$ fully agree with this statement. A total of $32(31.7 \%)$ i.e. a third of all students express concern about racial inequality.

The results of the Chi-square test: $\chi^{2}=16.802$, $\mathrm{df}=16, \mathrm{p}=0.399$ obtained by cross tabulating the statement $I$ am emotional concerned about racial inequality and the years of studies are not statistically significant, indicating that there is no difference in this attitude depending on the level of studies.

We can conclude that at all levels of education at the Faculty of Arts in Niš, students express the same attitudes on racial inequality - one third of students are concerned, one third is indifferent, while one third is not emotionally affected by racial inequality.

Based on the means $(\mathrm{M}=4,17, \mathrm{SD}=1,14)$ obtained on the statement I am not sensitive to the use of a language different than my mother tongue one can conclude that participants are not sensitive on the use of a different languages. A total of 52 students $(51.5 \%)$ fully agree with the statement, 30 students agree $(29.7 \%)$, which means that a total of 82 participants $(81.2 \%)$ is not sensitive and there is no concern about the use of a language different than their mother tongue. A total of 10 students or $9.9 \%$ are neutral, while $2(2.0 \%)$ do not agree with the claim, and 7 or $6.9 \%$ of students completely disagree. From the above data we can conclude that students of the Faculty of Arts in Niš are not sensitive to the use of languages different than their mother tongue.

By cross tabulating this claim with the year of study of participants, we obtain the results of the Chi-square test: $\chi^{2}=10.844, \mathrm{df}=16, \mathrm{p}=0.819$ which are not statistically significant. Based on the above, we conclude that there is no difference of the level of education of students on attitude I am not sensitive to the use of a language other than my mother tongue.

By the third group of questions, we wanted to determine if there are students involved in a struggle against racial and cultural prejudices, that is, whether they act in any way against racial and cultural differences. In the survey students were offered, options from number 1 (I do not agree at all) to 5 (I fully agree) which show the degree of agreement with this statement.

Regarding the issue of the spreading of racism I do not take anything to stop racism students were neutral. The largest number of participants circled number 3 on the Likert scale, 42 or $41.6 \%$ students. With this attitude 13 students $(12,9 \%)$ fully agree, while number 4 on the Likert scale or attitude I agree circling 19 students or $18,8 \%$. The obtained data show that $32(31.7 \%)$ participants would do nothing and in no way act to stop racism. With this statement 13 students $(12,9 \%)$ disagree, and 14 students $(13.9 \%)$ do not agree at all.

The results of frequency distribution indicate that students are indifferent to the given claim, that is, do not act in the struggle against racism. Also, we can conclude on the results from Chi-square test: $\chi 2=13,340, \mathrm{df}=16, \mathrm{p}=0,648$, which are not statistically significant, that students of all levels of study are neutral.

The results of frequency distribution for statement I help other people to neutralize language barriers that prevent communication with them are as follows:

- number 1 on the Likert scale, that is, the attitude I do not agree at all with the claim, circled by 4 students $(4.0 \%)$;

- number 2 on the same scale - attitude I do not agree, circled by $6(5,9 \%)$ students; 
- number 3 which confirms neutrality on the issue of the above statement circled by 36 $(35,6 \%)$ students;

- number 4 or attitude I agree (I help other people to overcome language barriers) - 36 or $35,6 \%$ students;

- number 5 , or absolute agreement with the attitude was expressed by 19 or $18,8 \%$ students.

The results show that a third of the students express indifference to language barriers, however, more than half of the students participate in helping to establish communication with people who have a problem with ignorance of the language.

By cross tabulating this statement with the year of study we obtained the following results of the Chi-square test: $\chi^{2}=27,192, \mathrm{df}=16, \mathrm{p}=0,039$. The results of asymptotic significance (Asymp. Sig.) indicate that there is a connection between the year of study and the attitude I help other people to overcome language barriers.

Table 3 Students`activity in overcoming language barriers, by year of studies

\begin{tabular}{|c|c|c|c|c|c|c|c|c|c|c|}
\hline & $\begin{array}{l}\text { I d } \\
\text { agre }\end{array}$ & $\begin{array}{l}\text { not } \\
\text { at all }\end{array}$ & & ree & $\begin{array}{c}\text { I neither agree } \\
\text { nor disagree }\end{array}$ & I agree & I fully agree & & Total & \multirow{7}{*}{$\begin{array}{c}\chi^{2}=27,192 \\
d f=16 \\
p=0,039\end{array}$} \\
\hline First & 0 & $0,0 \%$ & 3 & $13,6 \%$ & $8 \quad 36,4 \%$ & $836,4 \%$ & $13,6 \%$ & 22 & $100,0 \%$ & \\
\hline Second & 0 & $0,0 \%$ & 3 & $10,0 \%$ & $33,3 \%$ & $1240,0 \%$ & $16,7 \%$ & 30 & $100,0 \%$ & \\
\hline Third & 3 & $12,5 \%$ & 0 & $0,0 \%$ & $45,8 \%$ & $937,5 \%$ & $4,2 \%$ & 24 & $100,0 \%$ & \\
\hline Fourth & 0 & $0,0 \%$ & 0 & $0,0 \%$ & $40,0 \%$ & $426,7 \%$ & $33,3 \%$ & 15 & $100,0 \%$ & \\
\hline Master & 1 & $10,0 \%$ & 0 & $0,0 \%$ & $10,0 \%$ & $330,0 \%$ & $50,0 \%$ & 10 & $100,0 \%$ & \\
\hline Total & 4 & $4,0 \%$ & 6 & $5,9 \%$ & $35,6 \%$ & $3635,6 \%$ & $18,8 \%$ & 101 & $100,0 \%$ & \\
\hline
\end{tabular}

As they progress from lower to higher years of studies, students are more involved in overcoming the language barriers. The reason for this may be a higher level of knowledge of a language different from the mother tongue, as well as greater selfconfidence and relaxation in communication in a non-native language.

\subsection{Results and interpretation of the survey with examples of world music}

1. Hanzvadzi (Africa) 2. Jamaica Mento Music (Jamaica)

https://www.youtube.com/watch?v=cqSdmuT-vVw https://www.youtube.com/watch?v=aro4PaEgXM8 Means: $\mathrm{M}=3,64, \mathrm{SD}=0,98$.

\begin{tabular}{lcr}
\hline Likert scale & $\begin{array}{c}\text { Number of } \\
\text { students }\end{array}$ & $\%$ \\
\hline 1 (I don't like it at all) & 2 & 2,0 \\
2 (I don't like it) & 10 & 9,9 \\
3 (I am neutral) & 31 & 30,7 \\
4 (I like it) & 37 & 36,6 \\
5 (I like it very much) & 21 & 20,8 \\
\hline Total & 101 & 100,0 \\
\hline
\end{tabular}

Means: $\mathrm{M}=3,72, \mathrm{SD}=1,19$.

\begin{tabular}{lcr}
\hline Likert scale & $\begin{array}{c}\text { Number of } \\
\text { students }\end{array}$ & \multicolumn{1}{c}{$\%$} \\
\hline 1 (I don't like it at all) & 4 & 4,0 \\
2 (I don't like it) & 14 & 13,9 \\
3 (I am neutral) & 23 & 22,8 \\
4 (I like it) & 25 & 24,8 \\
5 (I like it very much) & 35 & 34,7 \\
\hline Total & 101 & 100,0 \\
\hline
\end{tabular}


3. Will Ye Go Lassie Go (Scotland)

https://www.youtube.com/watch?v=cb6FEONC8ro Means $\mathrm{M}=3,62, \mathrm{SD}=1,08$.

\begin{tabular}{lcr}
\hline Likert scale & $\begin{array}{c}\text { Number of } \\
\text { students }\end{array}$ & \multicolumn{1}{c}{$\%$} \\
\hline 1 (I don't like it at all) & 2 & 2,0 \\
2 (I don't like it) & 14 & 13,9 \\
3 (I am neutral) & 31 & 30,7 \\
4 (I like it) & 27 & 26,7 \\
5 (I like it very much) & 27 & 26,7 \\
\hline Total & 101 & 100,0 \\
\hline
\end{tabular}

5. Pontian (Greece)

https://www.youtube.com/watch?v=sQ5z_gRA-Yo Means: $\mathrm{M}=3,43, \mathrm{SD}=1,23$

\begin{tabular}{lcr}
\hline Likert scale & $\begin{array}{c}\text { Number of } \\
\text { students }\end{array}$ & \multicolumn{1}{c}{$\%$} \\
\hline 1 (I don't like it at all) & 8 & 7,9 \\
2 (I don't like it) & 15 & 14,9 \\
3 (I am neutral) & 29 & 28,7 \\
4 (I like it) & 24 & 23,8 \\
5 (I like it very much) & 25 & 24,8 \\
\hline Total & 101 & 100,0 \\
\hline
\end{tabular}

7. Makedonsko devojče (Macedonia)

Means $\mathrm{M}=4,61, \mathrm{SD}=0,81$.

\begin{tabular}{lcr}
\hline Likert scale & $\begin{array}{c}\text { Number of } \\
\text { students }\end{array}$ & \multicolumn{1}{c}{$\%$} \\
\hline 1 (I don't like it at all) & 2 & 2,0 \\
2 (I don't like it) & 3 & 3,0 \\
3 (I am neutral) & $/$ & $/$ \\
4 (I like it) & 22 & 21,8 \\
5 (I like it very mach) & 74 & 73,3 \\
\hline Total & 101 & 100,0 \\
\hline
\end{tabular}

9. AliAkbar Khan (India)

https://www.youtube.com/watch?v=qPeQlkJH_uk Means $\mathrm{M}=2,44, \mathrm{SD}=1,22$.

\begin{tabular}{lcr}
\hline Likert scale & $\begin{array}{c}\text { Number of } \\
\text { students }\end{array}$ & $\%$ \\
\hline 1 (I don't like it at all) & 28 & 27,7 \\
2 (I don't like it) & 29 & 28,7 \\
(I am neutral) & 22 & 21,8 \\
4 (I like it) & 16 & 15,8 \\
5 (I like it very much) & 6 & 5,9 \\
\hline Total & 101 & 100,0 \\
\hline
\end{tabular}

4. Havana lounge de Cuba (Cuba)

https://www.youtube.com/watch?v=yjidkg7JvP4 Means $\mathrm{M}=4,50, \mathrm{SD}=0,79$.

\begin{tabular}{lcr}
\hline Likert scale & $\begin{array}{c}\text { Number of } \\
\text { students }\end{array}$ & $\%$ \\
\hline 1 (I don't like it at all) & $/$ & $/$ \\
2 (I don't like it) & 3 & 3,0 \\
(I am neutral) & 10 & 9,9 \\
4 (I like it) & 21 & 20,8 \\
5 (I like it very much) & 67 & 66,3 \\
\hline Total & 101 & 100,0 \\
\hline
\end{tabular}

6. Mei Muata und mei Vota (Germany) https://www.youtube.com/watch?v=-Qm8FMnD-gQ Means $\mathrm{M}=2,82, \mathrm{SD}=1,10$.

\begin{tabular}{lcr}
\hline Likert scale & $\begin{array}{c}\text { Number of } \\
\text { students }\end{array}$ & $\%$ \\
\hline 1 (I don't like it at all) & 14 & 13,9 \\
2 (I don't like it) & 23 & 22,8 \\
3 (I am neutral) & 38 & 37,6 \\
4 (I like it) & 19 & 18,8 \\
5 (I like it very much) & 7 & 6,9 \\
\hline Total & 101 & 100,0 \\
\hline
\end{tabular}

8. Young Halya (Ukraine)

https://www.youtube.com/watch?v=caf32C6Vg5w Means $\mathrm{M}=2,55, \mathrm{SD}=1,01$.

\begin{tabular}{lcr}
\hline Likert scale & $\begin{array}{c}\text { Number of } \\
\text { students }\end{array}$ & $\%$ \\
\hline 1 (I don't like it at all) & 17 & 16,8 \\
2 (I don't like it) & 29 & 28,7 \\
3 (I am neutral) & 41 & 40,6 \\
4 (I like it) & 10 & 9,9 \\
5 (I like it very much) & 4 & 4,0 \\
\hline Total & 101 & 100,0 \\
\hline
\end{tabular}

10. Koto music (Japan) https://www.youtube.com/watch?v=AK51LblcEO Means $\mathrm{M}=2,30, \mathrm{SD}=1,06$.

\begin{tabular}{lcr}
\hline Likert scale & $\begin{array}{c}\text { Number of } \\
\text { students }\end{array}$ & $\%$ \\
\hline 1 (I don't like it at all) & 25 & 24,8 \\
2 (I don't like it) & 38 & 37,6 \\
3 (I am neutral) & 25 & 24,8 \\
4 (I like it) & 9 & 8,9 \\
5 (I like it very much) & 4 & 4,0 \\
\hline Total & 101 & 100,0 \\
\hline
\end{tabular}


11. Jasmine flower (China)

https://www.youtube.com/watch?v=9M4gca_uLB4 Means $\mathrm{M}=3,06, \mathrm{SD}=1,21$.

\begin{tabular}{lcr}
\hline Likertscale & $\begin{array}{c}\text { Number of } \\
\text { students }\end{array}$ & \multicolumn{1}{c}{$\%$} \\
\hline 1 (I don't like it at all) & 9 & 8,9 \\
2 (I don't like it) & 28 & 27,7 \\
3 (I am neutral) & 28 & 27,7 \\
4 (I like it) & 20 & 19,8 \\
5 (I like it very much) & 16 & 15,8 \\
\hline Total & 101 & 100,0 \\
\hline
\end{tabular}

13. Hava nagila (Israel)

https://www.youtube.com/watch?v=vHSNZK4Je-Y Means $\mathrm{M}=3,90, \mathrm{SD}=1,01$.

\begin{tabular}{lcr}
\hline Likert scale & $\begin{array}{c}\text { Number of } \\
\text { students }\end{array}$ & \multicolumn{1}{c}{$\%$} \\
\hline 1 (I don't like it at all) & 3 & 3,0 \\
2 (I don't like it) & 5 & 5,0 \\
3 (I am neutral) & 24 & 23,8 \\
4 (I like it) & 36 & 35,6 \\
5 (I like it very much) & 33 & 32,7 \\
\hline Total & 101 & 100,0 \\
\hline
\end{tabular}

15. Jigs and Reels (Ireland)

https://www.youtube.com/watch?v=_3xeTpgLP5o

Means $\mathrm{M}=3,97, \mathrm{SD}=0,99$.

\begin{tabular}{lcr}
\hline Likert scale & $\begin{array}{c}\text { Number of } \\
\text { students }\end{array}$ & \multicolumn{1}{c}{$\%$} \\
\hline 1 (I don't like it at all) & 2 & 2,0 \\
2 (I don't like it) & 6 & 5,9 \\
(I am neutral) & 21 & 20,8 \\
4 (I like it) & 36 & 35,6 \\
5 (I like it very much) & 36 & 35,6 \\
\hline Total & 101 & 100,0 \\
\hline
\end{tabular}

According to the data of means (M), the attitude of students toward the world music examples looks like this:
1. Russia $-\mathbf{M}=\mathbf{4 , 6 4}, \mathrm{SD}=0,64$
2. Macedonia $-\mathbf{M}=\mathbf{4 , 6 1}, \mathrm{SD}=0,81$
3. $\mathrm{Cuba}-\mathbf{M}=\mathbf{4 , 5 0}, \mathrm{SD}=0,79$
4. Ireland $-\mathbf{M}=\mathbf{3}, \mathbf{9 7}, \mathrm{SD}=0,99$
5. Israel $-\mathbf{M}=\mathbf{3 , 9 0}, \mathrm{SD}=1,01$
6. Jamaica $-\mathbf{M}=\mathbf{3 , 7 2}, \mathrm{SD}=1,19$
7. Africa $-\mathbf{M}=\mathbf{3 , 6 4}, \mathrm{SD}=0,98$
8. Scotland - $\mathbf{M}=\mathbf{3 , 6 2}, \mathrm{SD}=1,08$
9. Greece $-\mathbf{M}=\mathbf{3 , 4 3}, \mathrm{SD}=1,23$

12. Abou Ali (Arabic traditional music) https://www.youtube.com/watch?v=G6GR7P3PuPk Means $\mathrm{M}=2,83, \mathrm{SD}=1,23$.

\begin{tabular}{lcc}
\hline Likert scale & $\begin{array}{c}\text { Number of } \\
\text { students }\end{array}$ & $\%$ \\
\hline 1 (I don't like it at all) & 16 & 15,8 \\
2 (I don't like it) & 26 & 25,7 \\
3 (I am neutral) & 30 & 29,7 \\
4 (I like it) & 17 & 16,8 \\
5 (I like it very much) & 12 & 11,9 \\
\hline Total & 101 & 100,0 \\
\hline
\end{tabular}

\section{Kalinka (Russia)}

https://www.youtube.com/watch?v=qn06W-iBf Means $\mathrm{M}=4,64, \mathrm{SD}=0,64$.

\begin{tabular}{lcr}
\hline Likert scale & $\begin{array}{c}\text { Number of } \\
\text { students }\end{array}$ & \multicolumn{1}{c}{$\%$} \\
\hline 1 (I don't like it at all) & $/$ & $/$ \\
2 (I don't like it) & 1 & 1,0 \\
(I am neutral) & 6 & 5,9 \\
4 (I like it) & 21 & 20,8 \\
(I like it very much) & 73 & 72,3 \\
\hline Total & 101 & 100,0 \\
\hline
\end{tabular}


10. China $-\mathbf{M}=\mathbf{3 , 0 6}, \mathrm{SD}=1,21$

11. Arabic traditional music $-\mathbf{M}=\mathbf{2 , 8 3}, \mathrm{SD}=1,23$

12. Germany $-\mathbf{M}=\mathbf{2 , 8 2}, \mathrm{SD}=1,10$

13. Ukraina - $\mathbf{M}=\mathbf{2}, \mathbf{5 5}, \mathrm{SD}=1,01$

14. India $-\mathbf{M}=\mathbf{2}, \mathbf{4 4}, \mathrm{SD}=1,22$

15. Japan $-\mathbf{M}=\mathbf{2}, \mathbf{3 0}, \mathrm{SD}=1,06$

By cross tabulating the year of study and musical examples, the most liked - Russian folk song Kalinka - we obtained the results of the Chi-square test: $\chi 2=11,435, \mathrm{df}=12$, $\mathrm{p}=0,492$ which is not statistically significant and indicates that there is no difference in the students' opinion as far as the year of the study is concerned. At all levels of education, the favorite musical example is this Russian folk song.

The students least liked the Japanese folk song (Koto music). When the year of the study cross tabulating with the students' attitudes about this example we obtained the following results of the Chi-square test: $\chi 2=26,478, \mathrm{df}=16, \mathrm{p}=0,048$. The results are at the borderline of the statistical significance, which indicates that students' opinions differ from year to year. Measured by the ANOVA test (which indicates the difference in attitudes about the Japanese folk song by year of study) has statistical significance $(\mathrm{F}=3,871, \mathrm{p}=0,006)$ and post-hoc test revealed a significant difference on attitudes about the musical example Koto music (Japan) between the fourth $(\mathrm{M}=1,40, \mathrm{SD}=0,50)$ and all the other years of studies - first $(M=2,36, S D=0,95)$, second $(M=2,33, S D=1,02)$, third $(\mathrm{M}=2,63, \mathrm{SD}=1,20)$ and master $(\mathrm{M}=2,60, \mathrm{SD}=1,07)$.

\begin{tabular}{lcccccc}
\hline $\begin{array}{l}\text { Musical } \\
\text { example }\end{array}$ & $\begin{array}{l}\text { Year of } \\
\text { studies }\end{array}$ & $\mathrm{N}$ & $\mathrm{M}$ & $\mathrm{SD}$ & $\mathrm{F}$ & $\mathrm{p}$ \\
\hline \multirow{2}{*}{ Koto music } & first & 22 & 2,36 & 0,95 & & \\
(Japan) & second & 30 & 2,33 & 1,02 & & \\
& third & 24 & 2,63 & 1,20 & 3,871 & 0,006 \\
& fourth & 15 & 1,40 & 0,50 & & \\
\hline
\end{tabular}

\section{CONCLUSION}

Our research has studied the knowledge/awareness of the students of the Department of Music at the Faculty of Arts in Niš about the phenomenon of interculturality and its importance in the context of the contemporary art education, their care for/sensitivity to respecting cultural diversity and their activity with the purpose of preventing racial and cultural differences and prejudices. The survey was completed with a survey on the musical preferences of the students with selected examples of world music that represent different, close and distant music cultures. Most of the students agree with the fact that different languages are spoken. Students in the higher years of studies demonstrate a greater degree of engagement in removing language barriers. Half of the students fully understand and accept the concept of diversity, yet students in the beginning years of studies show more understanding for cultural diversity. At the same time, the results we have obtained point to the indifferent attitude of students and the lack of their action in the fight against racial and cultural prejudices. Based on the analysis of responses related to the examples of world music, one can notice that students show the highest preference for geographically and 
culturally (linguistically, religiously) close areas (Russia, Macedonia), while they have the least preference for the music of the Far East countries (India, China), that is, for the music that was created in a completely different system, both from western European music and from musical traditions close to them. Our research just points to the need to provide conditions for affirmation and studying of the music of other cultures and traditions by incorporating the world music into the teaching process. „If the criteria for inclusion of musical examples in the pluralistic curriculum were their sonority, expressiveness and musical interest, music education could indeed participate in the creation of a new values, in the transmission of culture and in critical reflection..." (Dobrota 2007, 127). Therefore it is very significant to encourage the importance of intercultural music education and through this kind of education contribute not only to the strengthening of tolerance towards different cultures, but also to the development of students' intercultural sensitivity.

Acknowledgement: The paper is the part of the project of Niš Branch of the Serbian Academy of Sciences and Arts (SASA): 0-10-17 "The Music Heritage of Southeast Serbia, Contemporary Creativity and the Formation of Taste".

\section{REFERENCES}

Abril, C. R. (2006). Music That Represents Culture: Selecting Music with Integrity. Music Educators Journal, 93(1), 38-45. https://doi.org/10.1177/002743210609300122

Arnautović, J. (2017). Interkulturni dijalozi na muzičkim festivalima u Srbiji [Intercultural dialogues at music festivals in Serbia]. Zvečan: Fakultet umetnosti Univerziteta u Prištini, Zvečan - Kosovska Mitrovica, 67.

Banks, J. A. (1988). Multicultural Education: Theory and Practice. Boston: Allyn and Bacon.

Bennett, J. M. \& Bennett, M. J. (2001). Developing intercultural sensitivity: An integrative approach to global and domestic diversity. Portland: The Intercultural Communication Institute.

Belojica Pavlović, B. \& Cicović Sarajlić, D. (2018). Nacionalno vaspitanje u nastavi muzičke kulture [National education in the teaching of music culture]. Leposavić/Kosovska Mitrovica: Učiteljski fakultet u Prizrenu Leposavić/Fakultet umetnosti u Prištini - Zvečan, 36.

Cvetković, J. \& Đurđanović, M. (2013). Nastava muzike kao deo multikulturološkog obrazovanja [Music teaching as a part of multicultural education], u: Dimitrijević, B. (ur.), Zbornik radova sa naučnog skupa sa međunarodnim učešćem Nauka i savremeni univerzitet - Znanje i korist. Niš: Univerzitet u Nišu, Filozofski fakultet, 158-168

Dekaney, E. M., Macede, E. C. \& Pye, L. R. (2011). University-School District World Drumming Partnerships: An Assessment of Students' Perception of the Value of Global Music and Culture in Their Lives and Schools. Applications of Research in Music Education, 29(2), 50-57. https://doi.org/10.1177/ 8755123310396979

Dobrota, S. (2009). Svjetska glazba u suvremenom glazbenom obrazovanju [World Music in the contemporary music education]. Pedagogijska istraživanja, 6(1-2), 153-161.

Dobrota, S. (2016). Povezanost između interkulturalnih stavova studenata i preferencija glazbi svijeta [The relationship between students' intercultural attitudes and world music preferences]. Život $i$ škola: časopis za teoriju i praksu odgoja i obrazovanja, 62(1), 209-218. https://hrcak.srce.hr/165133

Dobrota, S., Kovačević, S. (2007). Interkulturalni pristup nastavi glazbe [The intercultural approach to music teaching]. Pedagogijska istraživanja, 4(1), 119-129.

Erlmann, V. (1996), The aesthetics of the global imagination: reflections on world music in the 1990s. Public Culture, 8(3), 467-487.

Fung, C. V. (1994). Undergraduate Nonmusic Majors' World Music Preference and Multicultural Attitudes. Journal of Research in Music Education, 42(1), 45-57. http://www.jstor.org/stable/3345336

Henninger, J. (2018). Research-to-Resource: Effective incorporation of world music into the music classroom. Applications of Research in Music Education, 37(1), 5-8. https://doi.org/10.1177/8755123318774199

Mansikka, J. E., Westvall, M. \& Heimonen, M. (2018). Critical aspects of cultural diversity in music education: Examining the established practices and cultural forms in minority language schools in Finland. Intercultural Education, 29(1): 59-76. doi: 10.1080/14675986.2017.1404784 
Munroe, A. \& Pearson, C. (2006). The Munroe Multicultural Attitude Scale Questionnaire: A New Instrument for Multicultural Studies. Educational and Psychological Measurement, 66(5), 819-834. DOI: $10.1177 / 0013164405285542$

Ober, L. (2007). Muzika drugih [The music of the Other]. Beograd: Biblioteka XX vek.

Ristivojević, M. (2009). Uloga muzike u konstrukciji nacionalnog identiteta [The role of music in the construction of national identity]. Etnološko-antropološke sveske, 13 (2), 117-130.

Sulentić Begić, J. (2010). Glazba i interkulturalnost [Music and interculturality]. U: A. Peko, M. Sablić, R. Jindra (ur.), Zbornik radova s 2. međunarodne znanstvene konferencije Obrazovanje za interkulturalizam. Osijek: Sveučilište Josipa Jurja Strossmayera u Osijeku/Učiteljski fakultet u Osijeku/Nansen Dijalog Centar Osijek, 327-340.

\section{PREFERENCIJE STUDENATA MUZIKE PREMA ŽANRU WORLD MUSIC U KONTEKSTU PODSTICAJA INTERKULTURNOG OBRAZOVANJA}

$U$ radu se analizira fenomen world music i preferencije studenata muzike Fakulteta umetnosti Univerziteta u Nišu prema ovom muzičkom žanru $u$ kontekstu podsticaja interkulturnog obrazovanja. Istraživanje zasnovano na primeni deskriptivne metode sprovedeno je sa namerom da se dobiju odgovori na pitanja da li kod studenata muzike postoji znanje/spoznaja o interkulturalnosti, kakav je njihov stav prema različitim kulturama i da li su spremni da aktivno deluju protiv rasnih/kulturoloških razlika i predrasuda. Rezultati ovog ispitivanja upotpunjeni su rezultatima ankete kojom su studenti ocenjivali odabrane muzičke primere world music. Ovaj muzički žanr izabran je zbog stavova da se muzika percipira ne samo kao autonomna umetnička praksa već i kao reprezent određene kulture, kolektiva i/ili etničke grupe. Na osnovu dobijenih rezultata pokušali smo da utvrdimo reakcije studenata na muzičke karakteristike bližih i daljih kulturnih područja kao i njihovu spremnost da prihvate muzičke, jezičke i kulturolške različitosti s obzirom na još uvek prisutnu dominaciju zapadnoevropske umetničke muzike u procesu akademskog obrazovanja.

Ključne reči: studenti muzike, muzičko obrazovanje, interkulturanost, preferencija, world music 